\title{
Improving the Brake Control Effectiveness of Vehicles Equipped with a Pneumatic Brake Actuator
}

\author{
V. Bogomolov ${ }^{1)}$, V. Klimenko'), D. Leontiev ${ }^{1)}$, L. Ryzhyh ${ }^{1)}$, O. Smyrnov ${ }^{1)}$, M. Kholodov ${ }^{1)}$ \\ ${ }^{1)}$ Kharkiv National Automobile and Highway University (Kharkiv, Ukraine) \\ (C) Белорусский национальный технический университет, 2020 \\ Belarusian National Technical University, 2020
}

\begin{abstract}
This paper proposes a way to determine a rational connection between a two-section or three-section brake valve and the main brake system circuits of a wheeled vehicle equipped with simplex or duo-duplex brake gears. The aim is to determine a rational option to connect main brake system circuits with a brake valve to guarantee the maximum effectiveness of an emergency brake system if any device of the brake actuator of a multiaxle wheeled vehicle is out of order, using the methods of combinatorics. The feature of the proposed way, determining the rational connection of a brake valve with the main brake system circuits of a multiaxle wheeled vehicle, is the application of combinatorics methods, taking into account the features of a brake valve design. New mathematical interconnections between the quantities of the connection points of circuits and simplex and duo-duplex brake gears enable us to determine the rational scheme of the application of the brake gear circuits of a multiaxle wheeled vehicle. Mathematical expressions that enable us to compute the number of possible connection points of two-section and three-section brake gears and simplex and duo-duplex brake gears, which are installed on the axles of a multiaxle wheeled vehicle, have been determined. It is proposed to use a universal mathematical dependence to determine the number of rational options to connect the brake actuator circuits of a multiaxle wheeled vehicle. The diagram of the calculated scheme of the connection between circuits and the two-section or three-section brake valve of simplex or duo-duplex brake gears is presented. It simplifies the determination of the number of rational options to connect brake actuator circuits with the brake gears and brake valve of a multiaxle wheeled vehicle. In review the analysis of requirements to be fulfilled in accordance with international standards is provided and the evaluation of the effectiveness of the emergency brake system of some wheeled vehicles is carried out. The general concept to determine the rational layout of the emergency brake system of a multiaxle wheeled vehicle on the basis of the arrangement schemes of the connection between two-section or three-section brake valves and simplex and duo-duplex brake gears is proposed.
\end{abstract}

Keywords: multiaxle vehicle, pneumatic brake actuator, brake gear, effectiveness factor

For citation: Bogomolov V., Klimenko V., Leontiev D., Ryzhyh L., Smyrnov O., Kholodov M. (2020) Improving the Brake Control Effectiveness of Vehicles Equipped with a Pneumatic Brake Actuator. Science and Technique. 19 (1), 55-62. https://doi.org/10.21122/2227-1031-2020-19-1-55-62

\section{К вопросу о повышении эффективности управления тормозами транспортных средств, оснащенных пневматическим тормозным приводом}

\author{
В. Богомолов ${ }^{1)}$, В. Клименко ${ }^{1)}$, Д. Леонтьев ${ }^{1)}$, Л. Рыжих ${ }^{1)}$, О. Смирнов $^{1)}$, М. Холодов $^{1)}$ \\ ${ }^{1)}$ Харьковский национальный автомобильно-дорожный университет (Харьков, Украина)
}

Реферат. В статье предлагается способ определения рационального подключения двух- или трехсекционного тормозного крана к контурам рабочей тормозной системы многоосного колесного транспортного средства с тормозными механизмами типа «симплекс» или «дуо-дуплекс». Цель заключается в том, чтобы определить рациональный вариант подключения контуров рабочей тормозной системы к тормозному крану для обеспечения наивысшей эффективности действия запасной тормозной системы при выходе из строя какого-либо устройства, входящего в состав тормозного

$\begin{array}{ll}\text { Адрес для переписки } & \text { Address for correspondence } \\ \text { Леонтьев Дмитрий } & \text { Leontiev Dmytro } \\ \text { Харьковский национальный } & \text { Kharkiv National } \\ \text { автомобильно-дорожный университет } & \text { Automobile and Highway University } \\ \text { ул. Ярослава Мудрого, 25, } & 25 \text { Yaroslav Mudry str., } \\ \text { 61002, г. Харьков, Украина } & 61002, \text { Kharkiv, Ukraine } \\ \text { Тел.: +380 97 943-78-85 } & \text { Tel.: +380 97 943-78-85 } \\ \text { dima.a3alij@gmail.com } & \text { dima.a3alij@gmail.com }\end{array}$


привода многоосного колесного транспортного средства. Особенностью рассматриваемого способа является применение метода комбинаторики с учетом особенностей конструкции тормозного крана. Наличие математических взаимосвязей между количеством точек подключения контуров к тормозным механизмам типа «симплекс» или «дуодуплекс» позволяет найти рациональную схему использования контуров тормозного привода многоосного колесного транспортного средства. Определены математические выражения, с помощью которых можно рассчитать число возможных точек подсоединения двух- и трехсекционных тормозных кранов к тормозным механизмам «симплекс» или «дуо-дуплекс», установленным на осях многоосного колесного транспортного средства. Для определения количества рациональных вариантов подключения контуров тормозного привода многоосного колесного транспортного средства предложено использовать универсальную математическую зависимость. В графическом виде представлена расчетная схема подключения контуров к двух- или трехсекционному тормозному крану тормозных механизмов «симплекс» или «дуо-дуплекс», что упрощает задачу определения количества рациональных вариантов подключения. Приведен анализ требований, которые необходимо выполнить в соответствии с международными стандартами. Произведена оценка эффективности действия запасной тормозной системы некоторых типов колесных транспортных средств. Предложена общая концепция определения рациональной схемы организации запасной тормозной системы многоосного колесного транспортного средства на основе компоновочных схем подключения двух- или трехсекционных тормозных кранов к тормозным механизмам типа «симплекс» или «дуо-дуплекс», установленным на транспортном средстве.

Ключевые слова: многоосное транспортное средство, пневматический тормозной привод, тормозной механизм, коэффициент эффективности

Для цитирования: К вопросу о повышении эффективности управления тормозами транспортных средств, оснащенных пневматическим тормозным приводом / В. Богомолов [и др.] // Наука и техника. 2020. Т. 19, № 1. С. 55-62. https://doi.org/10.21122/2227-1031-2020-19-1-55-62

\section{Introduction}

International standards require that the brake control of a wheeled vehicle should include a main brake system and a parking brake system as well as an emergency brake system. According to international standards, the system is effective if it provides a minimum deceleration rate of $2.2 \mathrm{~m} / \mathrm{s}^{2}$ for vehicles of categories N2 and N3 and $2.5 \mathrm{~m} / \mathrm{s}^{2}$ for vehicles of categories M2 and M3. The standards also emphasise that in case the pneumatic circuit of a brake actuator has any failure, the remaining effectiveness of a main brake system must have a minimal braking deceleration as follows:

- for loaded vehicles of categories M2 and M3 $-1.5 \mathrm{~m} / \mathrm{s}^{2}$;

- for loaded vehicles of categories N2 and $\mathrm{N} 3-1.3 \mathrm{~m} / \mathrm{s}^{2}$;

- for unladen vehicles of categories M2 and $\mathrm{N} 3-1.3 \mathrm{~m} / \mathrm{s}^{2}$;

- for unladen vehicles of category M3 $1.5 \mathrm{~m} / \mathrm{s}^{2}$;

- for unladen vehicles of category $\mathrm{N} 2$ $1.1 \mathrm{~m} / \mathrm{s}^{2}$.

A percentage of the total effectiveness of a main brake system is as follows:

- for loaded vehicles of categories M2 and M3 - $30 \%$;

- for loaded vehicles of categories N2 and N3$26 \%$;
- for unladen vehicles of categories M2 and N3 - $26 \%$;

- for unladen vehicles of category M3 - 30\%;

- for unladen vehicles of category $\mathrm{N} 2-22 \%$.

A main operational brake system must provide a minimal deceleration rate of $5 \mathrm{~m} / \mathrm{s}^{2}$ for a vehicle of categories N2, N3, M2 or M3. In percentage terms of the total effectiveness of a main brake system, the effectiveness of an emergency brake system must be minimum:

- for vehicles of categories $\mathrm{N} 2$ and $\mathrm{N} 3-44 \%$;

- for vehicles of categories M2 and M3 - 50\%.

So, if the effectiveness of an emergency brake system is $50 \%$ minimum of the total effectiveness of a main brake system for vehicles of categories $\mathrm{N} 2, \mathrm{~N} 3, \mathrm{M} 2$ and M3, we will meet all international standards in terms of the effectiveness of the braking of a wheeled vehicle for both an emergency brake system and a main brake system in case any device of a brake actuator is out of order.

\section{Literature review}

One of the main requirements for a wheeled vehicle is stable braking without skidding. Therefore, this paper does not deal with a so called "diagonal" scheme of the separation of the circuits of main and emergency brake systems. Close attention is paid to the distribution of a brake system circuits along a wheeled vehicle axles to organise 
an emergency brake system on the basis of a main brake system. International standards allow such a layout of circuits. The layout is frequently used in the brake control of a vehicle of categories N2, $\mathrm{N} 3, \mathrm{M} 2$ and $\mathrm{M} 3$.

We will consider an emergency brake system of a two-axle vehicle. The emergency brake system is designed on the basis of a two-circuit main brake system (Fig. 1).

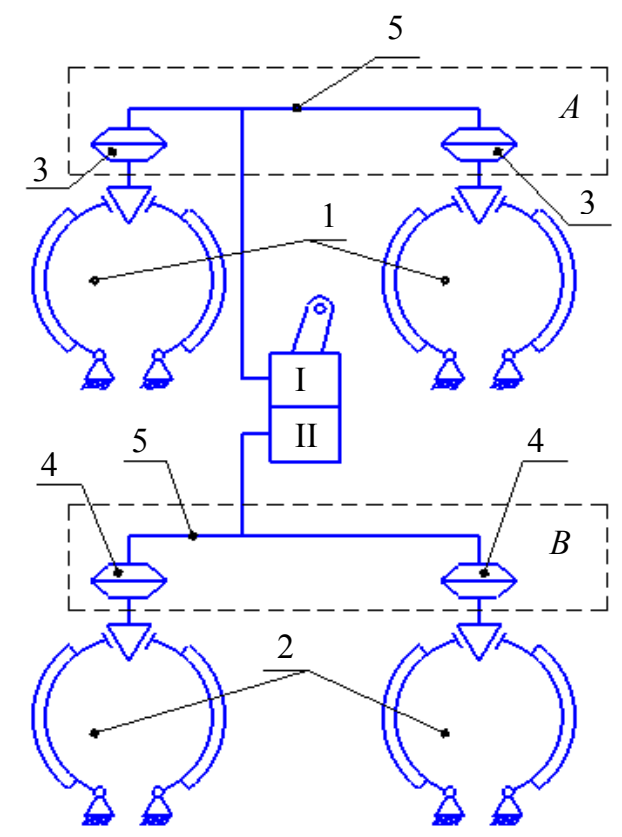

Fig. 1. Scheme of a two-circuit main brake system of a wheeled two-axle vehicle equipped with a pneumatic actuator with simplex brake gears: 1,2 - front and rear simplex brake gears; 3, 4-brake chambers of the front and rear axles of vehicle; 5 - pipelines; I - section of a brake valve that is connected with point $A$ where a brake circuit is connected with the corresponding brake chambers of axle; II - section of a brake valve that is connected with point $B$ where a brake circuit is connected with the corresponding brake chambers of axle; $A, B$-sequence places where a corresponding circuit is connected with brake chambers 3 and 4 of a front and rear axles

In general, the effectiveness of a main brake system of a vehicle has to meet the condition

$$
j_{e}=\frac{R_{x 1}+R_{x 2}}{m_{a}} \geq[j],
$$

where $R_{x 1}, R_{x 2}$ - total braking forces of the corresponding front and rear axles of a wheeled vehicle, $\mathrm{H} ; m_{a}-$ mass of a wheeled vehicle, $\mathrm{kg}$; $[j]=5 \mathrm{~m} / \mathrm{s}^{2}-$ permissible minimum deceleration of a braking wheeled vehicle when applying a main brake system.

In order to guarantee $50 \%$ effectiveness of an emergency brake system, if any device in the circuits of the front or rear axles of a wheeled vehicle is out of order, we will meet conditions:

$$
\begin{gathered}
j_{e 1}=\frac{R_{x 1}}{m_{a}} \geq 2.5 \mathrm{~m} / \mathrm{s}^{2} ; \\
j_{e 2}=\frac{R_{x 2}}{m_{a}} \geq 2.5 \mathrm{~m} / \mathrm{s}^{2} .
\end{gathered}
$$

Expressions (2) and (3) show that generally the decelerations that are available when a wheeled vehicle is braking can be unequal

$$
j_{e 1} \neq j_{e 2}
$$

that's, if we take into account expression (1), it looks as follows:

$$
j_{e i}=n_{i} j_{e} \geq 2.5 \mathrm{~m} / \mathrm{s}^{2},
$$

where $n_{i}$ - so-called effectiveness factor of the $i^{\text {th }}$ circuit that is involved in the braking of a vehicle.

Like expression (4), (5) means that, for example, for a wheeled two-axle vehicle the values of the effectiveness factors of the $i^{\text {th }}$ circuit are not equal in general case, that's, there is inequality

$$
n_{1} \neq n_{2}
$$

then, in a particular case if $j_{e}=5 \mathrm{~m} / \mathrm{s}^{2}$, expressions (1)-(3) clearly indicate that we will meet the condition

$$
n_{1} \geq 0.5 \leq n_{2}
$$

therefore, the effectiveness of an emergency brake system is the minimum value of effectiveness factors $n_{i}$ and a corresponding deceleration $j_{e i}$.

The practice of the brake control design for the vehicles of categories N2, N3, M2 and M3, for example, of special purpose or specialised ones, indicates that it is difficult to meet the condition (7). As a rule, it is due to controversial requirements that are stated in Annexes 4 and 10 of the international rules No 13 [1]. 
For example, computation shows that the agricultural vehicle KAZ-4540 [2] has the following ratio of the effectiveness factors of a front and rear axles:

$$
n_{1}=0.6 ; n_{2}=0.4
$$

It is obvious that condition (7) is not valid for such a vehicle.

According to the analysis of the research that is conducted at the Department of Vehicles named after A. B. Gredeskul in Kharkov National Automobile and Highway University, in case of (8), in order to meet requirement (5), it is necessary to guarantee the main brake system minimum effectiveness of $6.25 \mathrm{~m} / \mathrm{s}^{2}$ at the expense of constructive decisions that often complicate and raise the price of brake systems. For example, it is possible to improve the main brake system effectiveness due to the replacement of the simplex brake with the duo-duplex brake (Fig. 2) [3] as it is done in the design of the main brake system of the LiAZ-5256 [4] (Fig. 3).

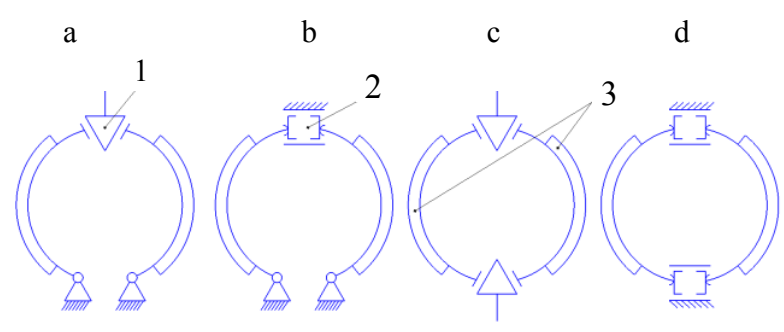

Fig. 2. Schemes of drum brake gears: a - simplex scheme with a pneumatic actuator and a wedge; $b$ - simplex scheme with a hydraulic actuator; $\mathrm{c}$ - duo-duplex scheme with a pneumatic actuator and a wedge;

$\mathrm{d}$ - duo-duplex scheme with a hydraulic actuator; 1 - wedge; 2 - main brake cylinder; 3 - brake shoe

According to Fig. 3, if one of the two circuits of the main brake system fails, the brake gears of a wheeled vehicle start operating as a simplex scheme instead of a duo-duplex scheme; it guarantees a wheeled vehicle braking effectiveness at the level of $68 \%$ minimum of the total effectiveness of a main brake system.

Condition (5) exceeds the minimum value as the effectiveness factors are $n_{1}=n_{2} \cong 0.68$.

One more way to improve the effectiveness of a main brake system is to increase the number of brake actuator circuits, for example, from two (Fig. 4) to three (Fig. 5). The implementation of a three-circuit main brake system is expedient for vehicles that have three axles minimum and three places minimum to connect corresponding circuits with brake chambers (Fig. 5).

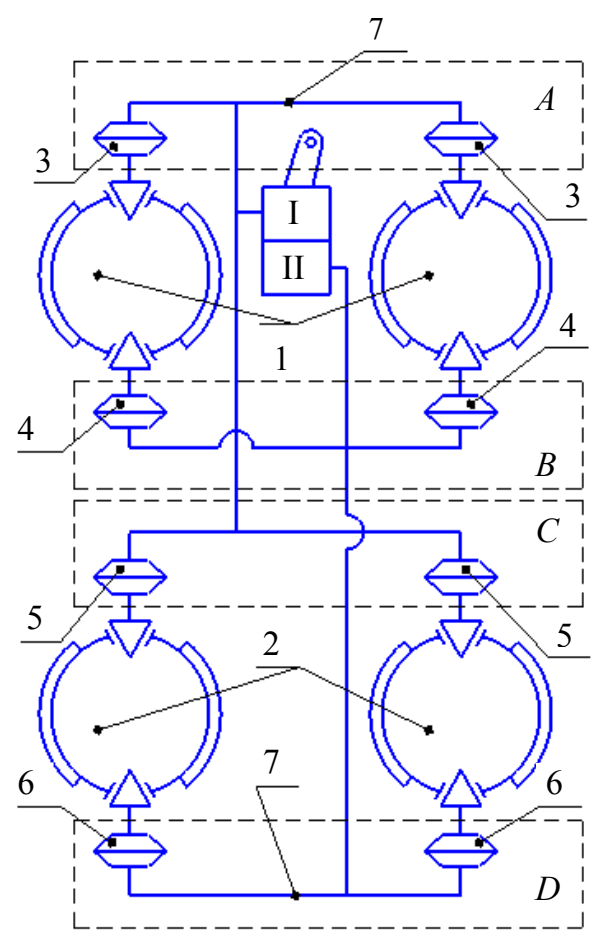

Fig. 3. Scheme of a dual circuit main brake system with a pneumatic actuator for a two-axle wheeled vehicle with duo-duplex brake gears; 1, 2 - duo-duplex front and rear brake gears correspondingly; 3, 4, 5, 6- brake chambers of the front and rear axles of a vehicle; 7 - pipelines;

I - brake valve section that is connected with places $A$ and $C$ where a brake circuit is connected with the brake chambers of front and rear axles; II - brake valve section that is connected with places $B$ and $D$ where a brake circuit is connected with the brake chambers of front and rear axles; $A, B, C, D$ - sequence places to connect a corresponding circuit with the corresponding brake chambers $3,4,5,6$ of front and rear axles

The analysis of scientific and technical literature $[2,3,5]$ shows that a three-circuit brake system becomes possible to use after the Public JointStock Company Volchansk Aggregate Plant (the town of Volchansk, Kharkiv region, Ukraine) has put into serial production a three-section brake valve (Fig. 6) that was designed by the Research and Production Enterprise Avtoagregat (the city of Kharkiv, Ukraine). 


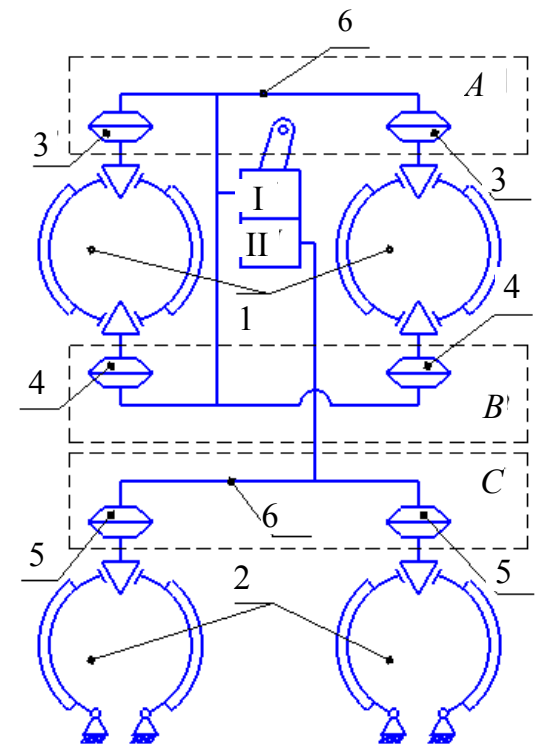

Fig. 4. Scheme of a dual circuit main brake system with a pneumatic actuator of a two-axle wheeled vehicle:

1 - duo-duplex front brake gear; 2 - simplex rear brake gear; $3,4,5$ - brake chambers of vehicle front and rear axles; 6 - pipelines; I - brake valve section that is connected with places $A$ and $B$ where a brake circuit is connected with the brake chambers of a front axle;

II - brake valve section that is connected with place $C$ where a brake circuit is connected with corresponding brake chambers of a rear axle; $A, B, C$-sequence places to connect a corresponding circuit to the brake chambers 3, 4, 5 of front and rear axles

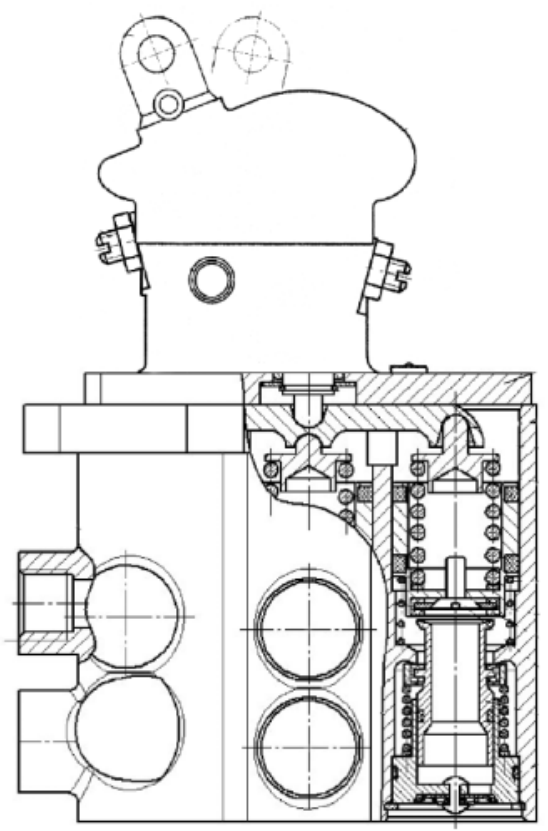

Fig. 6. Cross-section of a three-section brake valve that is manufactured at the Public Joint-Stock Company Volchansk Aggregate Plant

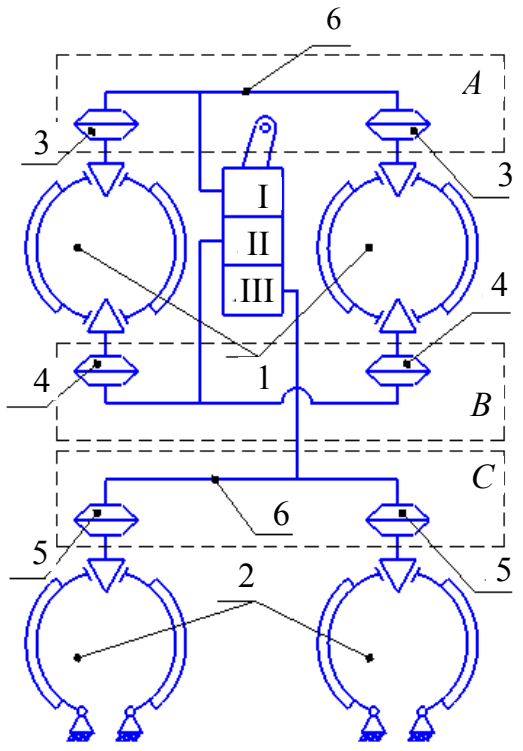

Fig. 5. Scheme of a three-circuit main brake system with a pneumatic actuator for a two-axle vehicle: 1 -duo-duplex front brake gear; 2 - simplex rear brake gear; 3, 4, 5-brake chambers of the front and rear axles of a vehicle; 6 - pipelines; I - brake valve section that is connected with place $A$ where a brake circuit is connected with the brake chambers of a front axle; II - brake valve section that is connected with place $B$ where a brake circuit is connected with the brake chambers of a front axle; III - brake valve section that is connected with place $C$ where a brake circuit is connected with the brake chambers of a rear axle; $A, B, C$-sequence places to connect

a corresponding circuit with the brake chambers $3,4,5$ of front and rear axles

The use of several circuits enables us to improve the effectiveness of an emergency brake system due to the simultaneous use of two circuits of three ones available if one of the main brake system circuits is out of order.

Calculations show that for the scheme in Fig. 5 the effectiveness factor of the first and second circuits, which take part in the braking of a wheeled vehicle, is 0.41 ; the effectiveness factor of the third circuit is 0.4 , according to (8).

Therefore, supposing that the first circuit is out of order, the two others left $\left(2^{\text {nd }}\right.$ and $3^{\text {rd }}$ circuits) guarantee $81 \%$ of a minimum vehicle braking effectiveness. The same is true if the second circuit is out of order.

If the third circuit is out of order, the first and second circuits are operational and the effectiveness of an emergency brake system is $82 \%$ minimum. It reliably guarantees the minimum deceleration of a wheeled vehicle due to an emergency brake system and it meets the requirements in terms of the effectiveness of an emergency brake system. 


\section{Aim and problem statement}

Taking into consideration the above-mentioned, the aim of the paper is to determine the regularities of the emergency brake system effectiveness change of the wheeled vehicles of categories $\mathrm{N} 2, \mathrm{~N} 3, \mathrm{M} 2$ and $\mathrm{M} 3$ when we vary the following parameters:

- the number of circuits (two or three) that compose a main brake system;

- the number of wheeled vehicle axles $\left(k_{m}\right)$ [6];

- types of brake gears: simplex and duo-duplex.

\section{Analysis of emergency brake system effectiveness change}

To determine the number of the most rational options of the component arrangement of emergency brake system circuits, the experiment planning theory can be used $[7,8]$. The total number of the rational options of the component arrangement of circuits can be calculated using this equation

$$
N_{r}=k^{m-k},
$$

where $k$ - number of the circuits of a main brake system (numbered by Arabic numerals in Fig. 2, 3); $m$ - number of possible points to connect circuits (lettered in Latin in Fig. 1, 3-5).

The number of possible combinations to connect circuits and brake gears can be determined, taking into account a type of a brake valve, on the basis of these expressions:

- for a two-section brake valve

$$
N=2^{m}-2
$$

- for a three-section brake valve

$$
N=3^{m}-3 \cdot 2^{m}+3 .
$$

For further analysis of possible variants to connect circuits and corresponding brake chambers, the following designation will be applied:

- for a dual circuit brake system

$$
\text { I - II; }
$$

- for a three-circuit brake system

$$
\text { I - II - III. }
$$

In expressions (12) and (13) Roman numerals designate a brake valve section number, which corresponds to a circuit number.

Each section of a brake valve can be connected with several points of brake chambers $A, B, C, D$ etc. So within one section of a brake valve (I, II or III) they will be designated as a fraction, for example, in accordance with Fig. 4, the designation of section I will be as follows:

$$
\mathrm{I} \rightarrow A / B,
$$

and designation of II correspondingly

$$
\text { II } \rightarrow C \text {. }
$$

Taking into consideration the above-mentioned, we will consider the rational options of circuit component arrangements under possible combinations of the points of connection with a brake valve.

For example, for dual circuit main brake systems that have two points to join circuits (Fig. 1) expressions (9) and (10) give the following results:

$$
\begin{aligned}
& N_{r}=2^{2-2}=1 ; \\
& N=2^{2}-2=2 .
\end{aligned}
$$

So one possible rational option of a circuit component arrangement has two possible combinations of connection, namely, according to (12), we will write $A-B$ or $B-A$ having the effectiveness factor $n_{1}=n_{2}=0.5$.

Under connection shown in Fig. 4, we will get:

$$
\begin{aligned}
& N_{r}=2^{3-2}=2 \\
& N=2^{3}-2=6 .
\end{aligned}
$$

So there can be two options for a rational circuit component arrangement and six combinations of connection, namely:

1) $A-B / C$ or $B / C-A$, or option $(A-C / B$ or $C / B-A)$;

2) $A / B-C$ or $C-A / B$.

Options $B / A-C$ or $C-B / A$ have no sense as the points of connection $A$ and $B$ belong to the same duo-duplex brake gear, in accordance with the scheme in Fig. 4.

In case the connection is made as in Fig. 3, we will get:

$$
\begin{gathered}
N_{r}=2^{4-2}=4 ; \\
N=2^{4}-2=14 .
\end{gathered}
$$

There are only four options of a rational circuit component arrangement and fourteen combinations of connection, according to the scheme in Fig. 3:

1) $A / B-C / D$ or $C / D-A / B$

2) $A / B / C-D$ or $D-A / B / C$, or option $(A / B / D-C$ or $C-A / B / D)$;

3) $A / C / D-B$ or $B-A / C / D$, or option $(B / C / D-A$ or $A-B / C / D$ )

4) $A / C-B / D$ or $B / D-A / C$, or option $(A / D-B / C$ or $B / C-A / D)$.

The other options for the scheme in Fig. 3 have no sense as the points of connection $A / B$ and $C / D$ belong to corresponding duo-duplex brake gears. 
When connecting a three-axle vehicle equipped with simplex brake gears and a two-section brake valve, we will have a scheme of a rational circuit component arrangement as for the brake actuator scheme in Fig. 4:

$$
\begin{aligned}
& N_{r}=2^{3-2}=2 ; \\
& N=2^{3}-2=6 .
\end{aligned}
$$

So there can be two options of a rational circuit component arrangement and six connection combinations:

1) $A-B / C$ or $B / C-A$, or option $(B-A / C$ or $A / C-B)$;

2) $A / B-C$ or $C-A / B$.

Other options have no sense as the rearrangement of axles that are united in one circuit does not change their effectiveness.

Changing from dual circuit systems to threecircuit ones, according to (9) and (11), a three-axle vehicle has the results:

$$
\begin{gathered}
N_{r}=3^{3-3}=1 ; \\
N=3^{3}-3 \cdot 2^{3}+3=6 .
\end{gathered}
$$

So there is only one option of a rational circuit component arrangement and six schemes to connect axles and a brake valve, namely: $A-B-C$ or $A-C-B$, or $B-A-C$, or $B-C-A$, or $C-B-A$, or $C-A-B$.

When a three-axle vehicle having a threesection brake gear has four points of connection, the number of rational circuit component arrangement and the connections between axles and a brake valve are as follows:

$$
\begin{gathered}
N_{r}=3^{4-3}=3 ; \\
N=3^{4}-3 \cdot 2^{4}+3=36 .
\end{gathered}
$$

So there are three options of a rational circuit component arrangement and 36 schemes to connect the points of corresponding axles with a brake valve.

When there are five points to connect a threeaxle vehicle with a three-section brake valve, according to (9) and (11), the results are as follows:

$$
\begin{gathered}
N_{r}=3^{5-3}=9 ; \\
N=3^{5}-3 \cdot 2^{5}+3=150 .
\end{gathered}
$$

The calculation shows that there are nine options of a rational circuit arrangement and 150 options to connect axles and a brake valve.

As we can see, the increase of the number of circuits and vehicle axles has the regularities of combinatorics. Therefore, the increase of combinations results in the increase of computation efforts.
As of the brake system effectiveness factor, according to international requirements [1], for threeaxle wheeled vehicles, we will have the following results:

$$
n_{1}=0.4 ; n_{2}=n_{3}=0.3 .
$$

For vehicles that have more than three axles or more than three points to connect circuits with the brake chambers of corresponding axles, according to scientific and technical literature [6, 9-12], the brake system effectiveness factor can be calculated as follows:

$$
n_{j}=\frac{1}{k_{m}},
$$

where $n$ - share of the $j^{\text {th }}$ axle effectiveness in the total effectiveness of a main brake system; $k_{m}$ number of wheeled vehicle axles.

On the basis of the $j^{\text {th }}$ axle effectiveness share in the main brake system total effectiveness, it is easy to determine the effectiveness factor of the $i^{\text {th }}$ circuit that is applied to brake a wheeled vehicle if we add the effectiveness shares of the axles that are connected with corresponding circuits of a vehicle.

The analysis of scientific and technical literature [6] has shown that further computations can involve axles $2,3,4,6,8,9,12$ only.

Thus, if we model a failure of a brake actuator circuit, the proposed approach can easily determine a wheeled vehicle braking effectiveness.

For example, let's compute the scheme in Fig. 4 and the results of the computation are provided in Tab. 1 to make the analysis easy. Tab. 1 shows that the most acceptable arrangement option is the connection scheme $A / B-C$ that corresponds to the circuit connection (1-1-2) as this scheme meets the condition (7) if any circuit is out or order.

Table 1

$$
\begin{aligned}
& \text { Possible variants of the rational circuit component } \\
& \text { arrangement effectiveness factors }
\end{aligned}
$$

for a wheeled vehicle emergency brake system

\begin{tabular}{|c|c|c|c|c|c|}
\hline \multicolumn{2}{|c|}{$\begin{array}{c}\text { No connection } \\
\text { point }\end{array}$} & $\begin{array}{c}\text { Failure } \\
\text { of } 1^{\text {st }} \text { circuit }\end{array}$ & $\begin{array}{c}\text { Failure } \\
\text { of } 2^{\text {nd }} \text { circuit }\end{array}$ & $\begin{array}{c}\text { Effectiveness } \\
\text { factor } \\
\text { of an emergency } \\
\text { brake system }\end{array}$ \\
\hline$A$ & $B$ & $C$ & & 0.84 & 0.34 \\
\hline 1 & 2 & 1 & 0.34 & 0.84 & 0.50 \\
\hline 1 & 1 & 2 & 0.50 & 0.50 & 0.34 \\
\hline 1 & 2 & 2 & 0.84 & 0.34 & \multicolumn{3}{|c}{} \\
\hline
\end{tabular}

Similarly, we can compute possible variants of the effectiveness factors of the rational emergency brake system circuit component arrangements for vehicles with more axles. For example, the effectiveness factors of the accepted axles are in Tab. 2. 
Possible variants of the effectiveness factors of the rational circuit component arrangements of an emergency brake system on the basis of a dual circuit and three-circuit main brake system

\begin{tabular}{|c|c|c|c|c|c|c|}
\hline \multirow[b]{3}{*}{$\begin{array}{c}\text { Wheeled } \\
\text { vehicle axles }\end{array}$} & \multicolumn{6}{|c|}{ Emergency brake system effectiveness factors } \\
\hline & \multicolumn{3}{|c|}{ Dual circuit main brake system } & \multicolumn{3}{|c|}{ Three-circuit main brake system } \\
\hline & $\begin{array}{l}\text { All simplex } \\
\text { brake gears }\end{array}$ & $\begin{array}{c}\text { Combination } \\
\text { of simplex brake } \\
\text { gears and duo-duplex } \\
\text { brake gears }\end{array}$ & $\begin{array}{c}\text { All duo-duplex } \\
\text { brake gears }\end{array}$ & $\begin{array}{l}\text { All simplex } \\
\text { brake gears }\end{array}$ & $\begin{array}{c}\text { Combination } \\
\text { of simplex brake } \\
\text { gears and duo-duplex } \\
\text { brake gears }\end{array}$ & $\begin{array}{l}\text { All duo-duplex } \\
\text { brake gears }\end{array}$ \\
\hline Two & 0.5 & 0.50 & 0.68 & $-{ }^{*}$ & 0.50 & 0.680 \\
\hline Three & 0.4 & 0.57 & 0.68 & 0.600 & 0.60 & 0.770 \\
\hline Four & 0.5 & 0.59 & 0.68 & 0.500 & 0.67 & 0.760 \\
\hline Six & 0.5 & $-{ }^{* *}$ & 0.68 & 0.667 & $-^{* *}$ & 0.787 \\
\hline Eight & 0.5 & $-^{* *}$ & 0.68 & $-^{* *}$ & $-^{* *}$ & $-^{* *}$ \\
\hline Nine & $-^{* *}$ & $-^{* *}$ & $-^{* *}$ & 0.667 & $-^{* *}$ & 0.786 \\
\hline Twelve & 0.5 & $-^{* *}$ & 0.68 & 0.667 & $-^{* *}$ & 0.787 \\
\hline
\end{tabular}

\section{CONCLUSIONS}

1. Emergency brake system effectiveness depends on the distribution of brake forces along the axles of a wheeled vehicle and does not depend on the quantity of axles.

2. Emergency brake system effectiveness increases as the quantity of main brake system circuits increases by $23 \%$ on average if simplex brake gears are used.

3. Emergency brake system effectiveness increases if the quantity of main brake system circuits increases by $27 \%$ on average when using duo-duplex brake gears instead of simplex brake gears.

\section{REFERENCES}

1. United Nations Economic Commission for Europe (2016) Regulation No 13 of the Economic Commission for Europe of the United Nations (UN/ECE). Uniform Provisions Concerning the Approval of Vehicles of Categories $M, N$ and $O$ with Regard to Braking. Available at: https://op.europa.eu/ en/publication-detail/-/publication/0a43f880-d612-11e5-a4 b5-01aa75ed71a1/language-en.

2. Frumkina K. A. (1984) KAZ-4540 "Colchis” Agricultural Dump Truck: Technical Description and Instruction Manual. Moscow, Mashinostroenie Publ. 280 (in Russian).

3. Turenko A. N., Bogomolov V. A., Klimenko V. I., Kirchatyi V. I., Khodyrev S. Ya. (2002) Improving Methods for Regulating the Output Parameters of the Brake System of Vehicles. Kharkiv, Kharkiv National Automobile and Highway University, 400 (in Russian).

4. Demkin V. V., Dremin A. P., Zatsepilov K. I., Stepnenko V. V. (2001) Bus LiAZ-5256 and its Modifications. Manual. Moscow, Atlasy Avtomobilei Publ. 512 (in Russian).

5. Turenko A. M., Bohomolov V. O., Klymenko V. I. and et. (2003) Functional Calculation of the Brake System of the Car with Drum Brakes and Regulator of Braking Forces. Kharkiv, Kharkiv National Automobile and Highway University, 120 (in Ukrainian).
6. Aksenov P. V. (1989) Multi-Axle Cars. Moscow, Mashinostroenie Publ. 280 (in Russian).

7. Barabashchuk V. I., Kredentser B. P., Miroshnichenko V. I. (1984) Engineering Experiment Planning. Kiev, Tekhnika Publ. 200 (in Russian).

8. Kononiuk A. E. (2011) Fundamentals of Scientific Research (General Theory of Experiment). Book 2. Kiev, KTN Publ. 452 (in Russian).

9. Leontev D. N., Ryizhih L. A., Lomaka S. I., Klimenko V. I. (2011) On the Methodology of Analysis and Selection of the Distribution of Braking Forces between the Axles of a Biaxial Vehicle. Izvestiya MGTU "MAMI", 1 (11), 31-35 (in Russian).

10. Turenko A. N., Leontev D. N., Klimenko V. I., Ryizhih L. A., Lomaka S. I. (2011) On the Methodology of Analysis and Selection of the Distribution of Braking Forces between the Axles of the Car, Taking into Account the Requirements of UN/ECE Regulation No 13. Avtomobil'nyi Transport. Sbornik Nauchnykh Trudov [Automobile Transport. Scientific Collection]. Kharkiv, Kharkiv National Automobile and Highway University, 29, 29-36. (in Russian).

11. Turenko A. N., Bogomolov V. A., Leontev D. N. (2016) A Method for Determining the Deceleration of a Multiaxial Car Based on the Realized Clutches of its Wheels and the Location of the Center of Mass Coordinate. Visnik Kharkivs'kogo Natsional'nogo Avtomobil'no-Dorozhnogo Universitetu $=$ Bulletin of Kharkiv State Automobile and Highway Technical University, 75, 13-17 (in Russian).

12. Mikhalevich N. G., Turenko A. N., Bogomolov V. A., Klimenko V. I., Ryzhikh L. A., Leont'ev D. N., Krasyuk A. N. (2015) The Implementation of Intelligent Functions in the Electronic-Pneumatic Brake Control of a Vehicle. Kharkiv, Kharkiv National Automobile and Highway University, 450 (in Russian).

Received: 08.10.2019

Accepted: 10.12.2019

Published online: 31.01 .2020 